STUDIA Z PRAWA WYZNANIOWEGO

Tom $21-2018$

DOI: https://doi.org/10.31743/spw.202

LUCJAN ŚWITO*

MAŁGORZATA TOMKIEWICZ**

\title{
ZAŚWIADCZENIE O BRAKU OKOLICZNOŚCI WYŁĄCZAJĄCYCH ZAWARCIE MAŁŻEŃSTWA W PROCEDURZE MATRIMONIUM PER PROCURA
}

\section{Streszczenie}

Artykuł prezentuje rozwiązania normatywne dotyczące procedury wystawiania, treści i znaczenia zaświadczenia o braku okoliczności wyłączających zawarcie małżeństwa, w kontekście regulacji związanych z zawieraniem małżeństwa przez pełnomocnika (matrimonium per procura). Zasadniczy cel i problem badawczy zawarty w publikacji oscyluje wokół odpowiedzi na pytanie, o braku jakich konkretnie okoliczności, dokument ten informuje; czy mechanizmy kontrolne towarzyszące wystawieniu tego zaświadczenia obejmują wymogi określone w art. $6 \S 1$ k.r.o. i czy dostrzegają specyfikę małżeństwa zawieranego przez pełnomocnika? Co konkretnie oznacza użyte $w$ art. $8 \S 1$ k.r.o. sformułowanie, iż duchowny „,nie może przyjąć oświadczeń przewidzianych w art. $1 \S 2$ [k.r.o.]" bez uprzedniego przedstawienia mu omawianego zaświadczenia i czy wskazany w tym przepisie zakaz dowodzi, że zaświadczenie o braku okoliczności wyłączających zawarcie małżeństwa ma charakter konstytutywny?

Artykuł stawia tezę, że o ile sama idea wystawiania omawianego zaświadczenia jest bez wątpienia słuszna, o tyle dostosowywanie przepisów k.r.o. i p.a.s.c. do Konkordatu poszło w omawianej materii za daleko. Skutkowało ono wprowadzeniem takich obostrzeń, które statuują wyraźny prymat formalizmu nad zasadą $f a$ vor matrimonii i dają asumpt do zróżnicowanej oceny charakteru tego zaświadczenia, w tym do formułowania tez o konstytutywnym charakterze tego dokumentu.

* Ks. dr hab., prof. UWM, Katedra Prawa Kanonicznego i Filozofii, Wydział Teologii, Uniwersytet Warmińsko-Mazurski w Olsztynie, ul. Kard. Hozjusza 15, 11-041 Olsztyn, e-mail: lucjan.swito@uwm.edu.pl. ORCID 0000-0002-6392-4599.

** Dr, Katedra Prawa Kanonicznego i Filozofii, Wydział Teologii, Uniwersytet Warmińsko-Mazurski w Olsztynie, ul. Kard. Hozjusza 15, 11-041 Olsztyn, e-mail margotom@, wp.pl. ORCID 0000-0001-8854-2928. 
Dla osób zamierzających zawrzeć małżeństwo w formie wyznaniowej ze skutkami cywilnymi wymóg legitymowania się zaświadczeniem mającym moc prawną stał się przesłanką w zasadzie analogiczną do tej, jaką mają inne, konstytutywne przesłanki małżeństwa, przy czym obostrzenie to nie ma charakteru powszechnego. Nie dotyczy ono nupturientów zamierzających zawrzeć małżeństwo przed kierownikiem USC lub konsulem (art. $1 \S \S 1$ i 4 k.r.o) a odnosi się tylko do tych, którzy zamierzają zawrzeć małżeństwo $\mathrm{w}$ formie wyznaniowej ze skutkami cywilnymi.

Istniejący stan rzeczy trudno uznać za właściwy. Mankamentem obowiązujących regulacji jest również to, że zaświadczenie o braku okoliczności wykluczających zawarcie małżeństwa, mimo iż zyskało znaczenie nieproporcjonalne do swej roli, „nie rozpoznaje” specyfiki małżeństw wyznaniowych ze skutkami cywilnymi zawieranymi per procura i w tym przypadku funkcji gwarancyjnych w należytym stopniu nie spełnia.

Słowa kluczowe: małżeństwo; zawarcie małżeństwa przez pełnomocnika; pełnomocnictwo; zaświadczenie o braku okoliczności wyłączających małżeństwo; przeszkody małżeńskie; kościoły i związki wyznaniowe

$* * * * *$

WSTĘP

Ustawa z dnia 24 lipca 1998 r. o zmianie ustawy - Kodeks rodzinny i opiekuńczy, Kodeks postępowania cywilnego, Prawo o aktach stanu cywilnego, ustawy o stosunku Państwa do Kościoła Katolickiego w Rzeczypospolitej Polskiej oraz niektórych innych ustaw ${ }^{1}$ wprowadziła zmiany w porządku prawnorodzinnym obowiązującym w Polsce od 1 stycznia $1946 \mathrm{roku}^{2}$. W miejsce istniejącej wyłącznie świeckiej formy zawarcia mał-

1 Dz. U. Nr 117, poz. 757.

2 W Polsce, w okresie przedwojennym, małżeństwa zawierane były według formy kościelnej, która jednocześnie wywierała skutki cywilne. W okresie II RP zawieranie małżeństw obowiązkowo odbywało się w formie religijnej, tzn. zgodnie z prawem Kościoła Katolickiego lub innego związku wyznaniowego i jako takie było uznawane przez państwo, zgodnie z prawem wcześniej obowiązującym w państwach zaborczych. Jedynie w byłym zaborze pruskim obowiązkowe były małżeństwa cywilne. Sytuacja diametralnie się zmieniła, gdy do władzy doszli komuniści. W ramach tzw. laicyzacji, na mocy dekretu Rady 
żeństwa przed kierownikiem USC, została wprowadzona druga - prawnie ważna - forma zawarcia małżeństwa. Z chwilą wprowadzenia tych zmian, zawierając związek wyznaniowy nupturienci mogą oświadczyć przed duchownym wolę jednoczesnego zawarcia małżeństwa podlegającego prawu polskiemu. Oświadczenie to wywoła zamierzony skutek cywilnoprawny, o ile kierownik USC sporządzi następnie akt małżeństwa. Zmiany te były konsekwencją ratyfikowania Konkordatu z dnia 28 lipca 1993 r. zawartego pomiędzy Stolicą Apostolską a Rzecząpospolitą Polską ${ }^{3}$.

Zgodnie z art. 1 § 2 k.r.o. ${ }^{4}$ małżeństwo zostaje zawarte, gdy mężczyzna i kobieta zawierający związek małżeński podlegający prawu wewnętrznemu kościoła albo innego związku wyznaniowego w obecności duchownego oświadczą wolę jednoczesnego zawarcia małżeństwa podlegającego prawu polskiemu i kierownik USC następnie sporządzi akt małżeństwa, przy czym - zgodnie z $\S 3$ tego przepisu - regulację tę stosuje się jeżeli ratyfikowana umowa międzynarodowa lub ustawa regulująca stosunki między państwem a kościołem albo innym związkiem wyznaniowym przewiduje możliwość wywołania przez związek małżeński podlegający prawu wewnętrznemu tego kościoła albo innego związku wyznaniowego takich skutków, jakie pociąga za sobą zawarcie małżeństwa przed kierownikiem USC.

W odniesieniu do Kościoła Katolickiego podstawę, do której nawiązuje wymieniony przepis, stanowi Konkordat oraz norma art. 15a ust. 1 ustawy z dnia 17 maja 1989 r. o stosunku Państwa do Kościoła Katolickiego w Rzeczpospolitej Polskiej5, natomiast wobec Autokefalicznego Kościoła Prawosławnego, Kościoła Ewangelicko-Augsburskiego, Kościoła Ewangelicko-Reformowanego, Kościoła Ewangelicko-Metodystycznego,

Ministrów z 25 września 1945 r. - Przepisy wprowadzające prawo o aktach stanu cywilnego - zarządzili obligatoryjne śluby cywilne, a małżeństwa kościelne pozbawili skutków cywilnoprawnych. Sytuacja w zakresie zawierania małżeństw ponownie się zmieniła podczas transformacji ustrojowej w III RP (zob. Krukowski, Warchałowski 2000, 52).

Konkordat między Stolicą Apostolską a Rzecząpospolitą Polską podpisany w Warszawie dnia 28 lipca 1993 r. (Dz.U. z 1998 r. Nr 51, poz. 318), ratyfikowany ustawą z dnia 8 stycznia 1998 r. (Dz.U. Nr 12, poz. 42).

4 Ustawa z dnia 25 lutego 1964 r. Kodeks rodzinny i opiekuńczy, Dz.U. Nr 9, poz. 682 z późn. zm., dalej jako „k.r.o.”.

5 Dz.U. Nr 29, poz. 154 z późn. zm. 
Kościoła Chrześcijan Baptystów, Kościoła Adwentystów Dnia Siódmego, Kościoła Polskokatolickiego, Kościoła Starokatolickiego Mariawitów, Kościoła Zielonoświątkowego oraz gmin wyznaniowych żydowskich stosowne nowele ,ustaw wyznaniowych"

W polskim prawie rodzinnym obowiązuje niekwestionowana zasada jednoczesnej obecności stron przy zawieraniu małżeństwa. Została ona wyrażona w art. $1 \S 1$ k.r.o., który wyraźnie stanowi, iż małżeństwo zostaje zawarte, gdy nupturienci jednocześnie obecni złożą stosowne oświadczenia. Zasada ta, akceptowana powszechnie w prawie małżeńskim również innych krajów, wynika z uznania doniosłości instytucji małżeństwa oraz osobistego charakteru oświadczenia o wstąpieniu w związek małżeński.

Przedstawiona zasada nie jest jednak pozbawiona wyjątku. Norma art. $6 \S 1$ k.r.o. stanowi, iż z ważnych powodów sąd może zezwolić, żeby oświadczenie o wstąpieniu w związek małżeński lub oświadczenie przewidziane w art. $1 \S 2$ k.r.o. zostało złożone przez pełnomocnika, przy czym pełnomocnictwo powinno być udzielone na piśmie z podpisem urzędowo poświadczonym i wymieniać osobę, z którą małżeństwo ma być zawarte (art. $6 \S 2$ k.r.o.).

Zawarcie małżeństwa przez pełnomocnika nie jest instytucją stosowaną dowolnie i nie zależy wyłącznie od decyzji samych nupturientów. Dla skutecznego zawarcia matrimonium per procura konieczne jest - zgodnie z treścią przywołanego art. $6 \S 1$ k.r.o. - uzyskanie zezwolenia sądu, przy czym zezwolenie to może być udzielone wówczas, gdy istnieją ku temu „ważne powody”. Jakie powody należą do tej kategorii i co konkretnie należy rozumieć pod wymienionym pojęciem - tego ustawodawca nie precyzuje, pozostawiając tę kwestię judykaturze i doktrynie. W literaturze przedmiotu przyjmuje się, że za tego rodzaju powody można uznać tylko takie okoliczności, które uniemożliwiają stawienie się nupturientom w jakimkolwiek miejscu, przy jednoczesnej niemożności przesunięcia daty zawarcia małżeństwa. Ocena ważności tych powodów w każdym przypadku zależy od okoliczności konkretnej sprawy i pozostawiona jest swobodnemu uznaniu sądu ${ }^{7}$. Za typowe ważne powody w praktyce przyjmuje się

6 Zob. ustawa z dnia 26 czerwca 1997 r. o zmianie ustawy o gwarancjach wolności sumienia i wyznania oraz o zmianie niektórych ustaw (Dz.U. z 1998 r. Nr 59, poz. 375).

Żurawińska 2012, 131-157. 
takie sytuacje, jak trudności polityczne związane z wyjazdem z innego kraju i przyjazdem do Polski, służba wojskowa, np. w siłach ONZ, obłożna choroba zakaźna ${ }^{8}$.

Bez względu na to, czy małżeństwo wyznaniowe ze skutkami cywilnymi miałoby być zawarte przez nupturientów obecnych osobiście, czy też z udziałem pełnomocnika, ustawowym wymogiem jest przedstawienie osobie duchownej, przed którą małżeństwo ma być zawarte, zaświadczenia stwierdzającego brak okoliczności wyłączających zawarcie małżeństwa. Zaświadczenie to jest dokumentem stwierdzającym, że na chwilę jego wydawania nie istnieją żadne okoliczności wyłączające zawarcie małżeństwa pomiędzy osobami wskazanymi w jego treści. Jak przyjmuje się w literaturze przedmiotu, wydanie zaświadczenia o braku okoliczności wyłączających zawarcie małżeństwa jest elementem kontroli państwa nad małżeństwami zawieranymi w formie wyznaniowej a mającymi uzyskać skutek cywilny 9 .

\section{POSTĘPOWANIE W PRZEDMIOCIE UZYSKANIA ZAŚWIADCZENIA}

Zgodnie z art. $4^{1} \S 1$ k.r.o. osobom zamierzającym zawrzeć małżeństwo w sposób określony w art. $1 \S 2$ i 3, kierownik USC wydaje zaświadczenie stwierdzające brak okoliczności wyłączających zawarcie małżeństwa oraz treść i datę złożonych przed nim oświadczeń w sprawie nazwisk przyszłych

8 Zielonacki 1982, 102 i 112; Haak 1999, 75-76; Piasecki 2011, 17. Zgodnie natomiast z poglądami judykatury, w tym uchwałą składu siedmiu sędziów Sądu Najwyższego z dnia 8 czerwca 1970 r. w sprawie III CZP 27/70 (OSNC 1971, nr 1, poz. 2, LEX nr 1116) za ważne powody w rozumieniu art. $6 \S 1$ k.r.o. należy uznać tylko takie okoliczności, które w świetle zasad współżycia społecznego usprawiedliwiają odstąpienie od obowiązku jednoczesnego stawienia się przyszłych małżonków przed kierownikiem urzędu stanu cywilnego dla złożenia oświadczenia, że wstępują ze sobą w związek małżeński. Żadna z góry określona sytuacja osoby ubiegającej się o zezwolenie jej na złożenie przez pełnomocnika oświadczenia o wstąpieniu w związek małżeński, w szczególności także fakt jej zamieszkiwania za granicą oraz związane z tym trudności przyjazdu do Polski, nie mogą być same przez się uznane za ważne powody w rozumieniu powołanego wyżej przepisu. Zezwoleń na zawarcie małżeństwa przez pełnomocnika udzielają sądy rejonowe w formie postanowienia, po przeprowadzeniu postępowania w trybie nieprocesowym.

9 Domański 2017, 65. 
małżonków i ich dzieci. Poza kierownikiem $\mathrm{USC}^{10}$, organem administracji publicznej uprawnionym do wydania wymienionego zaświadczenia jest również zastępca kierownika USC ${ }^{11}$. Nupturienci składając wniosek o wydanie wskazanego zaświadczenia nie są obecnie związani żadną zasadą określającą właściwość miejscową urzędu i mogą w tej sprawie zwrócić się do kierownika USC dowolnie wybranego przez siebie (art. 15 ust. 2 p.a.s.c.) ${ }^{12}$.

Wnioskując o wydanie wymienionego zaświadczenia, osoby zamierzające zawrzeć małżeństwo powinny złożyć lub przedstawić kierownikowi USC dokumenty niezbędne do zawarcia małżeństwa, określone w odrębnych przepisach (art. $3 \S 1$ k.r.o.), przy czym - jak wynika to z treści art. 76 ust.1 p.a.s.c. - obowiązane są uczynić to osobiście. Jeśli otrzymanie dokumentu, który osoba zamierzająca zawrzeć małżeństwo jest obowiązana złożyć lub przedstawić kierownikowi USC, napotyka trudne do przezwyciężenia przeszkody, sąd może zwolnić tę osobę od obowiązku złożenia lub przedstawienia tego dokumentu (art. 3 § 2 k.r.o.).

Zgodnie z art. 76 ust. 1 p.a.s.c. do dokumentów niezbędnych do zawarcia małżeństwa należą: dowody tożsamości, pisemne zapewnienia ${ }^{13}$

10 Kierownikiem USC z mocy samego prawa jest wójt (burmistrz, prezydent miasta). Na stanowisku kierownika USC może też zostać zatrudniona inna osoba. W okręgach liczących poniżej 50 tys. mieszkańców, wójt (burmistrz, prezydent miasta) obligatoryjnie zatrudnia zastępcę kierownika urzędu stanu cywilnego oraz fakultatywnie może zatrudnić inną osobę na stanowisku kierownika urzędu stanu cywilnego (art. 6 ust. 4 ustawy z dnia 28 listopada 2014 r. Prawo o aktach stanu cywilnego, Dz.U. z 2014 r., poz. 1741, dalej jako „p.a.s.c.”). W okręgach liczących powyżej 50 tys. mieszkańców wójt (burmistrz, prezydent miasta) obligatoryjnie zatrudnia inną osobę na stanowisku kierownika urzędu stanu cywilnego oraz fakultatywnie może zatrudnić zastępcę lub zastępców kierownika urzędu stanu cywilnego (art. 6 ust. 5 p.a.s.c.), zob. Tunia 2017, 81 i 84.

11 Zob. art. 9 ust. 2 p.a.s.c.

12 Możliwość taka wynika z tzw. „odmiejscowienia” niektórych czynności z zakresu rejestracji stanu cywilnego, dokonanego w ustawie z dnia 28 listopada 2014 r. Prawo o aktach stanu cywilnego.

13 Zapewnienie to zawiera: 1) nazwiska i imiona osób zamierzających zawrzeć małżeństwo, ich nazwiska rodowe, jeżeli można je ustalić, stan cywilny, obywatelstwo, daty i miejsca urodzenia, numery PESEL, jeżeli zostały nadane, oraz oznaczenia przedstawionych dokumentów tożsamości; 2) jeżeli osoba zamierzająca zawrzeć małżeństwo pozostawała uprzednio w związku małżeńskim albo prawomocnie stwierdzono nieistnienie małżeństwa - wskazanie miejsca zawarcia małżeństwa; 3) informację o wspólnych dzieciach osób zamierzających zawrzeć małżeństwo oraz oznaczenie ich aktów urodzenia i urzędu stanu cy- 
o braku wiedzy co do istnienia między nupturientami okoliczności wyłączających zawarcie małżeństwa, oświadczenia o wyborze nazwiska (nazwisk), które będą nosili po zawarciu małżeństwa, oświadczenia w sprawie nazwisk dzieci zrodzonych z tego małżeństwa, a także zezwolenia na zawarcie małżeństwa, jeżeli wymagają tego przepisy k.r.o. W myśl art. 76 ust. 3 p.a.s.c. jeśli oświadczenie o wstąpieniu w związek małżeński ma być złożone przez pełnomocnika, osoba zamierzająca wstąpić w związek małżeński przedkłada zezwolenie sądu na złożenie oświadczenia o wstąpieniu w związek małżeński przez pełnomocnika oraz pełnomocnictwo.

W sytuacji, gdy po zweryfikowaniu prawnej zdolności nupturientów do zawarcia małżeństwa kierownik USC uzna, że nie występują okoliczności wyłączające zawarcie małżeństwa, wydaje wskazane wyżej zaświadczenie. W przypadku natomiast stwierdzenia okoliczności negatywnych, kierownik USC odmawia wydania przedmiotowego zaświadczenia oraz powiadamia na piśmie osobę zainteresowaną o przyczynach odmowy (art. 5 k.r.o. $\mathrm{i}$ art. 89 ust. 1 pkt 2 p.a.s.c.). Osoba zainteresowana w terminie 14 dni od dnia doręczenia jej pisma kierownika USC może wystąpić z wnioskiem do sądu rejonowego właściwego ze względu na siedzibę urzędu stanu cywilnego o rozstrzygnięcie, czy okoliczności przedstawione przez kierownika USC uzasadniają odmowę dokonania czynności. Prawomocne postanowienie sądu wiąże kierownika USC.

W przypadku powzięcia wątpliwości co do tego, czy małżeństwo może być zawarte, kierownik USC może z własnej inicjatywy zwrócić się do sądu o stosowne rozstrzygnięcie (art. 5 k.r.o.) ${ }^{14}$. W uzasadnieniu wyroku z dnia

wilnego, w którym zostały sporządzone, jeżeli są znane; 4) nazwiska, imiona oraz nazwiska rodowe rodziców każdej z osób zamierzających zawrzeć małżeństwo; 5) jeżeli małżeństwo ma zostać zawarte w sposób określony w art. 1 § 2 i 3 Kodeksu rodzinnego i opiekuńczego - oświadczenia o nazwisku (nazwiskach), które będą nosiły osoby zamierzające zawrzeć małżeństwo po jego zawarciu, oraz oświadczenia o nazwisku dzieci zrodzonych z tego małżeństwa; 6) oświadczenie, że nie zachodzą przeszkody uniemożliwiające zawarcie małżeństwa określone w art. 10-15 Kodeksu rodzinnego i opiekuńczego; 7) informację o pouczeniu o odpowiedzialności karnej za złożenie fałszywego oświadczenia; 8) adres do korespondencji osób zamierzających zawrzeć małżeństwo; 9) podpisy osób zamierzających zawrzeć małżeństwo oraz kierownika urzędu stanu cywilnego albo konsula przyjmującego zapewnienie.

14 Zgodnie z postanowieniem Naczelnego Sądu Administracyjnego w Warszawie z dnia 7 czerwca 1983 r. w sprawie II SA 594/83, wystąpienie kierownika USC na podstawie art. 5 k.r.o. o rozstrzygnięcie, czy małżeństwo może być zawarte, nie jest decyzją w rozu- 
22 lutego 2012 r. w sprawie IV CSK 240/11'15, Sąd Najwyższy stwierdził, że jeżeli kierownik USC poweźmie uzasadnioną wątpliwość co do stanu zdrowia nupturienta i jego zdolności do zawarcia związku małżeńskiego lub złożenia oświadczenia o wstąpieniu w związek małżeński, może zażądać stosownego zaświadczenia lekarskiego. Sąd Najwyższy podkreślił, że powyższy wymóg nie jest wprawdzie wskazany w żadnym przepisie, jednak wynika ,z ogólnych zasad starannego i rozsądnego działania przy wykonywaniu obowiązków urzędnika państwowego"16. Wydanie zaświadczenia przez kierownika USC nie ma charakteru decyzji administracyjnej lecz jest inną formą załatwienia sprawy ${ }^{17}$.

Zgodnie $\mathrm{z}$ art. $4^{1} \S 2$ k.r.o. zaświadczenie o braku okoliczności wyłączających zawarcie małżeństwa traci moc po upływie sześciu miesięcy od dnia jego wydania. W doktrynie zwraca się uwagę, iż po utracie mocy przez wymienione zaświadczenie osoby zamierzające zawrzeć małżeństwo w formie wyznaniowej ze skutkami cywilnymi muszą powtórzyć wszystkie czynności potrzebne do zawarcia małżeństwa, a więc ponownie złożyć dokumenty, o których mowa w art. 3 k.r.o. oraz ponownie uzyskać zaświadczenie, o którym mowa $\mathrm{w}$ art. $4^{1} \S 1$ k.r.o. ${ }^{18}$

\section{TREŚĆ ZAŚWIADCZENIA}

Zaświadczenie sporządza się według wzoru stanowiącego załącznik nr 26 do rozporządzenia Ministra Spraw Wewnętrznych z dnia 29 stycznia 2015 r. w sprawie wzorów dokumentów wydawanych z zakresu rejestracji stanu cywilnego ${ }^{19}$, przy czym zawiera ono dane, które zostały taksatywnie wymienione w art. 81 ust.1 p.a.s.c.

W części wstępnej zaświadczenia zamieszczana jest data i miejsce jego wydania oraz oznaczenie organu wydającego zaświadczenie. W pkt. 1

mieniu art. 104 k.p.a. w zw. z art. $1 \S 1$ pkt 1 k.p.a. i nie podlega zaskarżeniu w administracyjnym toku instancji (zob. LEX nr 1688594).

15 LEX nr 1217052.

16 Tamże.

17 Borysiak 2014, 58.

18 Tamże.

19 Dz.U. z 2015 r., poz. 194. 
zaświadczenie to zawiera stwierdzenie, iż ,pomiędzy niżej wymienionymi osobami nie zachodzą okoliczności, które według prawa polskiego wyłączałyby zawarcie małżeństwa" oraz wskazuje podstawę prawną i określa cel, w jakim jest ono wydawane. W pkt. 2 podaje dokładne dane ${ }^{20}$ osób, które zamierzają zawrzeć małżeństwo, a w pkt. 3 dokładne dane ich rodziców. Pkt 4 zawiera oświadczenia osób, które zamierzają zawrzeć małżeństwo w sprawie nazwisk, jakie osoby te będą nosiły po zawarciu małżeństwa oraz nazwisko, jakie będą nosiły dzieci zrodzone z tego małżeństwa, a także datę złożenia wskazanego oświadczenia, osobno przez kobietę i mężczyznę. Pkt 5 określa termin ważności zaświadczenia, zaś w pkt. 6 przewidziane jest miejsce na złożenie własnoręcznego podpisu przez kierownika USC oraz na pieczęć z imieniem, nazwiskiem i stanowiskiem służbowym. Treść tego dokumentu zamyka pieczęć urzędowa.

Zatrzymując się przy wskazanym wyżej sformułowaniu - będącym istotą tego zaświadczenia - a sprowadzającym się do stwierdzenia, iż pomiędzy stronami nie zachodzą okoliczności wyłączające zawarcie małżeństwa, należałoby zapytać, o braku jakich konkretnie okoliczności dokument ten informuje? Zaświadczenie kwestii tej bezpośrednio nie wyjaśnia. Odpowiedzi udziela natomiast art. 81 ust. 1 p.a.s.c, który określając precyzyjnie dane, jakie w zaświadczeniu tym mają być zawarte, w pkt. 5 stwierdza, iż zaświadczenie to zawiera ,zapewnienie, że nie zachodzą przeszkody, o których mowa w art. 10-15 Kodeksu rodzinnego i opiekuńczego". Z powyższego wynikałoby zatem, iż kierownik USC wystawiając zaświadczenie o braku okoliczności wyłączających zawarcie małżeństwa informuje o braku pomiędzy stronami jedynie tych przeszkód, które wymienione są w art. 10-15 k.r.o. czyli, że pomiędzy stronami nie zachodzi przeszkoda wieku, ubezwłasnowolnienia całkowitego, choroby psychicznej lub niedorozwoju umysłowego, bigamii, pokrewieństwa i powinowactwa oraz przysposobienia. O tym, że omawiane zaświadczenie dotyczy tylko przeszkód wymienionych w art. 10-15 k.r.o. świadczy także treści art. 76 ust.6 p.a.s.c, który określa informacje zawarte w treści złożonego przez strony zapewnienia. Z brzmienia wymienionego przepisu wynika, iż zapewnienie zawiera adnotację o zweryfikowaniu danych przedstawionych w zapewnieniu zło-

20 Do danych tych należą: imię pierwsze, imię drugie, imiona kolejne, nazwisko, nazwisko rodowe, stan cywilny, data urodzenia, miejsce urodzenia. 
żonym przez osobę zamierzającą zawrzeć związek małżeński (a więc danych odnoszących się do przeszkód określonych w art. 10-15 k.r.o. - zob. art. 76 ust. 4 pkt. 6 p.a.s.c), ze wskazaniem dokumentów, na podstawie których dokonano weryfikacji lub oznaczenia aktów stanu cywilnego.

Wymienione zaświadczenie nie odnosi się do określonych $\mathrm{w}$ art. 6 k.r.o. wymogów dotyczących przesłanek zawarcia małżeństwa przez pełnomocnika. Analizowany dokument nie przewiduje też żadnej formy ewentualnej adnotacji faktu przedłożenia przez stronę/strony stosownego zezwolenia sądu na matrimonium per procura oraz pełnomocnictwa do zawarcia małżeństwa.

Taki stan rzeczy może budzić pewne zdumienie, bowiem wobec treści przytoczonego wyżej art. 76 ust. 3 p.a.s.c, który wyraźnie określa wymóg przedłożenia kierownikowi USC wymienionych dokumentów (przy czym przepis ten nie zawęża owego wymogu wyłącznie do małżeństw zawieranych jedynie w formule świeckiej), brak korelacji tego wymogu z treścią wydawanego przez kierownika USC zaświadczenia wydaje się być istotnym mankamentem. Jeśli bowiem zaświadczenie o braku okoliczności wyłączających zawarcie małżeństwa nie przewiduje żadnej wzmianki co do tego, czy strony przedstawiły kierownikowi USC zezwolenie sądu na zawarcie małżeństwa przez pełnomocnika oraz pełnomocnictwo do dokonania tej czynności, z treści tego dokumentu nie sposób się zorientować, czy nupturienci zamierzają zawrzeć matrimonium per procura i czy wymogi określone w art. $6 \S 1$ k.r.o. były przedmiotem weryfikacji kierownika USC. Tymczasem, uzyskanie wspomnianego zezwolenia sądu oraz udzielenie ważnego pełnomocnictwa nie jest bynajmniej okolicznością o znaczeniu marginalnym. Niedopełnienie powyższych wymogów może pociągać za sobą poważne konsekwencje gdyż zgodnie z art. 16 k.r.o. małżeństwo zawarte w sytuacji braku zezwolenia sądu na zawarcie małżeństwa przez pełnomocnika lub w przypadku nieważności pełnomocnictwa (albo jego skutecznego odwołania ${ }^{21}$ ) może zostać unieważnione.

21 Pełnomocnictwo do zawarcia małżeństwa traci swą moc prawną w przypadku śmierci mocodawcy, drugiego z nupturientów lub pełnomocnika; spełnienia czynności, do dokonania której zostało wystawione (tj. zawarcia małżeństwa); upływu okresu na jaki zostało udzielone. W polskiej judykaturze prawnorodzinnej podkreśla się, iż odwołanie pełnomocnictwa nie wymaga zachowania żadnej formy szczególnej i może zostać dokonane 
Wracając do samego zaświadczenia odnotować należy, iż pierwotnie było ono wystawiane w czterech egzemplarzach, z czego trzy wydawano nupturientom celem przekazania ich osobie duchownej ( $\$ 18$ ust. 2 rozporządzenia Ministra Spraw Wewnętrznych i Administracji z 26 października 1998 r. w sprawie szczegółowych zasad sporządzania aktów stanu cywilnego, sposobu prowadzenia ksiąg stanu cywilnego, ich kontroli, przechowywania i zabezpieczenia oraz wzorów aktów stanu cywilnego, ich odpisów, zaświadczeń i protokołów ${ }^{22}$ ). Obecnie, zgodnie z treścią art. 81 ust. 2 p.a.s.c zaświadczenie to wydaje się w dwóch egzemplarzach, przy czym jeden egzemplarz jest przeznaczony dla kościoła albo innego związku wyznaniowego, w którym jest zawierane małżeństwo, a drugi dla kierownika USC właściwego do sporządzenia aktu małżeństwa. Do zaświadczenia tego kierownik USC dołącza 3 egzemplarze formularza zaświadczenia stwierdzającego, że oświadczenia o wstąpieniu w związek małżeński zostały złożone w obecności duchownego; egzemplarze te, wypełnione przez duchownego, są przeznaczone dla osób, które zawarły małżeństwo, dla kościoła albo innego związku wyznaniowego, w którym zawarto małżeństwo, oraz dla kierownika USC właściwego do sporządzenia aktu małżeństwa (art. 81 ust. 3 p.a.s.c).

DEKLARATYWNY CZY KONSTYTUTYWNY CHARAKTER ZAŚWIADCZENIA?

Zgodnie z art. $8 \S 1$ k.r.o. duchowny przed którym zawierany jest związek małżeński podlegający prawu wewnętrznemu kościoła albo innego związku wyznaniowego, nie może przyjąć oświadczeń przewidzianych w art. $1 \S 2$ k.r.o. - bez uprzedniego przedstawienia mu zaświadczenia stwierdzającego brak okoliczności wyłączających zawarcie małżeństwa, sporządzonego przez kierownika USC.

Analiza powyższej regulacji rodzi pytanie, co konkretnie oznacza użyte w tym przepisie sformułowanie, iż „duchowny nie może” i czy wskazany w tym przepisie zakaz dowodzi, że zaświadczenie o braku okoliczności

w sposób dorozumiany (zob. wyrok Sądu Najwyższego z dnia 4 listopada 1998 r., II CKN 866/97, OSNC 1999, nr 3, poz. 66).

22 Dz.U. Nr 136, poz. 884 z późn. zm. 
wyłączających zawarcie małżeństwa ma charakter konstytutywny? Kwestia ta w literaturze przedmiotu bywa postrzegana niejednolicie.

Według G. Jędrejka jeżeli duchowny przyjął oświadczenia pomimo braku zaświadczenia, o którym mowa w art. $4^{1}$ k.r.o. należy uznać, że małżeństwo nie wywoła skutku cywilnego, a jedynie wyznaniowy. Brzmienie przepisu art. $8 \S 1$ k.r.o. w sposób kategoryczny wskazuje - zdaniem tego autora - że przedstawienie zaświadczenia $\mathrm{z}$ art. $4^{1}$ k.r.o. stanowi konstytutywną przesłankę zawarcia małżeństwa wyznaniowego, które wywoła skutek cywilny. Uzasadniając swoje stanowisko G. Jędrejek stwierdził, iż przepisy dotyczące takich przesłanek wymagają wykładni ścisłej. Oznacza to, że przedstawienie zaświadczenia po odebraniu oświadczeń, o których mowa w art. $1 \S 2$ k.r.o. jest bezskuteczne.

Podobny pogląd w tej kwestii prezentuje T. Smyczyński, według którego omawiane zaświadczenie jest dokumentem niezbędnym dla skutecznego dokonania na jego podstawie dalszych czynności prawnych ${ }^{23}$. Tak też uważają inni przedstawiciele doktryny prawnorodzinnej, między innymi H. Haak ${ }^{24}$ i W. Borysiak ${ }^{25}$.

W doktrynie nie brak jednak głosów diametralnie odmiennych, wskazujących, iż nawet całkowity brak owego zaświadczenia (lub upływ terminu jego ważności) nie oznacza, że nupturienci zawierając związek małżeński w takiej sytuacji nie osiągną zamierzonego skutku prawnego. Według R. Sobańskiego przedłożenie zaświadczenia nie należy bowiem do elementów konstytutywnych zdarzenia prawnego, którego skutkiem jest powstanie cywilnoprawnego stosunku małżeńskiego. Autor ten, w artykule polemicznym do poglądów T. Smyczyńskiego zauważył, iż Kodeks rodzinny i opiekuńczy nie uznaje braku zaświadczenia jako okoliczności wykluczającej zawarcie małżeństwa; nie ma przepisu, który stanowiłby, iż ,nie mogą zawrzeć małżeństwa osoby nie posiadające zaświadczenia" wydanego nie dawniej niż przed upływem wskazanego terminu ${ }^{26}$. Ustawa nie wiąże też z ,utratą mocy" zaświadczenia, rygoru nieważności dalszych czynności prawnych ${ }^{27}$.

\footnotetext{
23 Smyczyński 2002, 167.

24 Haak 1999, 90.

25 Borysiak 2014, 58.

26 Sobański 2003, 32.

27 Tamże.
} 
Poglądom R. Sobańskiego kwestionującym konstytutywny charakter omawianego zaświadczenia trudno odmówić racji. Za trafnością tych poglądów zdaje się przemawiać przede wszystkim fakt, iż treść owego zaświadczenia nie wiąże duchownego, mającego przyjąć oświadczenia małżonków o zawarciu związku małżeńskiego. Oznacza to że np. w sytuacji, gdy przed przystąpieniem do ceremonii zaślubin duchowny stwierdzi, iż jeden $\mathrm{z}$ nupturientów znajduje się $\mathrm{w}$ stanie wskazującym na poważne mankamenty psychiczne (np. jest w stanie urojeniowo-maniakalnym) nie odbierze od stron wymienionych oświadczeń, bez względu na to, że przedłożone mu zaświadczenie wskazuje na brak okoliczności wyłączających zawarcie małżeństwa. Podobnie nie wiąże również i sądu procedującego w przedmiocie unieważnienia małżeństwa. Dla sądu istotne znaczenie nie będzie miało to, czy strony w dacie zawierania małżeństwa miały ważne zaświadczenie którym mowa $\mathrm{w}$ art. $4^{1}$ k.r.o. lecz to, czy w tej dacie owe przeszkody faktycznie istniały. Jeśli takich przeszkód nie było, to ewentualny brak zaświadczenia (lub jego nieważność) nie mogą stanowić przyczyny unieważnienia małżeństwa. Zgodnie z zasadą numerus clausus wyrażoną w art. 17 k.r.o., unieważnienie może nastąpić tylko z przyczyn przewidzianych w Dziale I, Tytułu I k.r.o., a te - jak słusznie zauważył to R. Sobański - takiej przyczyny nie przewidują.

$\mathrm{Z}$ drugiej jednak strony nie można nie dostrzegać i tego, że ustawodawca zarówno w przepisach Kodeksu rodzinnego i opiekuńczego, jak i Prawie o aktach stanu cywilnego, wyraźnie nadał zaświadczeniu o braku okoliczności wyłączających zawarcie małżeństwa bardzo istotne znaczenie. W procedurze sporządzenia aktu małżeństwa, wymóg doręczenia tego zaświadczenia wraz z zaświadczeniem duchownego o złożeniu przez nupturientów stosownych oświadczeń kierownikowi USC, stanowi warunek sine qua non wystawienia aktu małżeństwa. Art. $8 \S 3$ k.r.o. jednoznacznie stanowi, iż oba wymienione zaświadczenia duchowny obowiązany jest przekazać do urzędu stanu cywilnego przed upływem pięciu dni od dnia zawarcia małżeństwa, zaś art. 87 ust. 3 p.a.s.c. ${ }^{28}$ równie jednoznacznie stwierdza, iż akt małżeństwa zawartego w sposób określony w art. 1 $\S 2$ i 3 Kodeksu rodzinnego i opiekuńczego sporządza się na podstawie

28 Analogiczną regulację przewidywał art. 61a ust. 1 p.a.s.c. w brzmieniu obowiązującym do 1 marca $2015 \mathrm{r}$. 
zaświadczenia stwierdzającego brak okoliczności wyłączających zawarcie małżeństwa oraz zaświadczenia stwierdzającego, że oświadczenia o wstąpieniu w związek małżeński zostały złożone w obecności duchownego.

W świetle tych przepisów, brak wskazanego zaświadczenia dotyczącego okoliczności wyłączających zawarcie małżeństwa, uniemożliwia dopełnienie wskazanego wyżej wymogu polegającego na przekazaniu tego dokumentu do urzędu stanu cywilnego, a tym samym uniemożliwia dopełnienie warunku konstytutywnego małżeństwa jakim jest sporządzenie aktu małżeństwa. Skoro wymogiem ustawowym, zawartym zarówno w k.r.o, jak i p.a.s.c jest wymóg przekazania do USC omawianego zaświadczenia, trudno racjonalnie przypuszczać, aby bez owego zaświadczenia jakikolwiek kierownik USC wystawił akt małżeństwa lub by w przypadku odmowy sporządzenia aktu, jakikolwiek sąd rejonowy taką decyzję zmienił. Uznając zatem zaświadczenie o braku okoliczności wyłączających zawarcie małżeństwa za dokument konieczny dla sporządzenia aktu małżeństwa przyjąć należy, że w takim sensie zaświadczenie to (samo w sobie) ma charakter współkonstytutywny.

Osobnej uwagi wymagałaby jednak analiza dwóch przypadków, gdy owo zaświadczenie wprawdzie zostało wystawione i zostało przesłane przez duchownego do USC w ciągu pięciu dni od zawarcia małżeństwa, jednakże albo było zaświadczeniem, które w dacie składania oświadczeń o zawarciu małżeństwa utraciło już swą moc prawną albo było zaświadczeniem ważnym, jednak zostało przedstawione osobie duchownej dopiero po złożeniu przez nupturientów wspomnianych oświadczeń. W obu tych przypadkach nie ma - jak wydaje się - podstaw natury zarówno formalnej, jak i aksjologicznej, które uzasadniałyby odmowę sporządzenia aktu małżeństwa. W tych sytuacjach uznać należałoby, iż skoro spełniony został ustawowy wymóg polegający na przesłaniu do USC wszystkich żądanych dokumentów, w terminie zakreślonym ustawą, to brak jest podstawy prawnej, która expressis verbis wskazywałaby na niedopuszczalność sporządzenia aktu małżeństwa. Podstawą taką nie mógłby być przepis mówiący o terminie, w którym zaświadczenie traci moc, gdyż - przywołując raz jeszcze wspomniane wyżej, trafne stanowisko R. Sobańskiego - ustawa nie wiąże z utratą mocy prawnej zaświadczenia rygoru nieważności dalszych skutków prawnych. De facto wskazany termin ma charakter jedynie porządkowy. Również użyte przez ustawodawcę sformułowanie, iż „duchowny 
nie może" przyjąć od nupturientów oświadczeń o zawarciu małżeństwa, jeżeli w dacie składania tych oświadczeń nie zostało przedstawione mu zaświadczenie o braku okoliczności wyłączających zawarcie małżeństwa, nie może stanowić podstawy do ewentualnej odmowy sporządzenia aktu małżeństwa, skoro także i ta regulacja nie została opatrzona żadną ,sankcją”. Art. $8 \S 1$ k.r.o. określa pewną - ze wszech miar uzasadnioną i słuszną - powinność osoby duchownej, jednak powinności tej nie należy utożsamiać z niedopuszczalnością, której skutkiem jest nieważność czynności.

$\mathrm{Na}$ marginesie odnotować należy, iż w odniesieniu do Kościoła Katolickiego analogiczna regulacja zawarta została w „Instrukcji Konferencji Episkopatu Polski dla duszpasterzy” z dnia 22 października 1998 r., która stanowi, iż proboszcz nie może załatwiać formalności związanych z zawarciem małżeństwa, jeżeli nie zostanie mu przedstawione ważne zaświadczenie kierownika USC (nr 13), zaś posługiwanie się zaświadczeniem wedle ustalonego wzoru dla przekazania informacji z Urzędu Stanu Cywilnego określono jako obowiązek (nr 18). Uchybienie powyższej regulacji nie oznacza jednak nieważności tak zawartego małżeństwa w świetle prawa kanonicznego. Zgodnie z poglądem powszechnie przyjętym w doktrynie kanonicznej, naruszenie powyższego zakazu nie stanowi przyczyny stwierdzenia nieważności małżeństwa, a jest jedynie niegodziwym działaniem asystującego ${ }^{29}$.

Sytuację, w której charakter prawny zaświadczenia o braku okoliczności wyłączających zawarcie małżeństwa nie jest zdefiniowany jednoznacznie i bywa oceniany różnie, w zależności od realiów danej sprawy - trudno uznać za optymalną.

Przyczyna takiego stanu rzeczy sięga okresu dostosowywania wskazanych we Wstępie przepisów prawnorodzinnych w zakresie zawarcia małżeństwa do postanowień Konkordatu z 1993 r. i wynika - jak wydaje się - z nadmiernego formalizmu ustawodawcy polskiego. W tym miejscu przypomnieć warto, iż (abstrahując od zgłaszanych w doktrynie wątpliwości, co do tego, czy Konkordat zawiera konstytutywne warunki małżeństwa $^{30}$ ) umowa ta statuuje tylko trzy przesłanki skutecznego zawarcia małżeństwa w formie wyznaniowej ze skutkami cywilnymi. W art. 10 ust. 1

\footnotetext{
29 Majer 2004, 280.

30 Szerzej zob. Majer 2001, 150.
} 
akt ten stanowi, iż od chwili zawarcia małżeństwo kanoniczne wywiera takie skutki, jakie pociąga za sobą zawarcie małżeństwa zgodnie z prawem polskim, jeżeli: 1) pomiędzy nupturientami nie istnieją przeszkody wynikające z prawa polskiego; 2) złożą oni przy zawieraniu małżeństwa zgodne oświadczenie woli dotyczące wywarcia takich stuków; 3) zawarcie małżeństwa zostało wpisane w aktach stanu cywilnego na wniosek przekazany urzędowi stanu cywilnego w terminie pięciu dni od zawarcia małżeństwa; termin ten ulega przedłużeniu, jeżeli nie został dotrzymany z powodu siły wyższej, do czasu ustania tej przyczyny. Jak zatem z powyższej regulacji wynika, w odniesieniu do procedury wpisania małżeństwa w akta stanu cywilnego Konkordat mówi jedynie o konieczności przekazania do urzędu stanu cywilnego w terminie pięciu dni stosownego wniosku. Ani formy tego wniosku, ani rodzaju dokumentów, które na wniosek ten winny się składać, Konkordat bliżej nie określa.

\section{PODSUMOWANIE}

Zaświadczenie o braku okoliczności wyłączających zawarcie małżeństwa jest dokumentem, którego rolę trudno przecenić. Pełni ono istotne funkcje gwarancyjne a celowość jego wystawienia i znaczenie praktyczne na etapie poprzedzającym zawarcie małżeństwa, są oczywiste. Nie oznacza to jednak, że dokument ten żadnych kontrowersji nie budzi.

Sama idea wystawiania omawianego zaświadczenia jest słuszna, jednak dostosowywanie przepisów Kodeksu rodzinnego i opiekuńczego oraz Prawa o aktach stanu cywilnego do Konkordatu poszło - jak wydaje się w omawianej materii za daleko. Skutkowało ono wprowadzeniem takich obostrzeń, które statuują wyraźny prymat formalizmu nad zasadą favor matrimonii $^{31}$ i dają asumpt do zróżnicowanej oceny charakteru tego zaświadczenia, w tym do formułowania tez o konstytutywnym charakterze tego dokumentu. Dla niemałej części doktryny prawnorodzinnej, ważne zaświadczenie o braku okoliczności wykluczających zawarcie małżeństwa, stanowi (zawsze) przesłankę konstytutywną. Według tej opcji, przedstawienie omawianego zaświadczenia po odebraniu oświadczeń, o których

31 Szerzej zob. Świto 2014, 59-70. 
mowa w art. $1 \S 2$ k.r.o. lub w sytuacji, gdy zaświadczenie to utraciło moc powoduje to, że małżeństwo nie wywoła skutku cywilnego. Wymogi zawarte w art. $8 \S 3$ k.r.o. i art. 86 ust. 3 p.a.s.c. wskazujące, iż podstawą sporządzenia aktu małżeństwa, jest przesłanie w określonym terminie owego zaświadczenia, w praktyce wyklucza możliwość wystawienia aktu małżeństwa, jeśli wymóg ten nie zostanie spełniony, i to nawet jeśli pomiędzy stronami żadne przeszkody nie istnieją.

Dla osób zamierzających zawrzeć małżeństwo w formie wyznaniowej ze skutkami cywilnymi wymóg legitymowania się zaświadczeniem mającym moc prawną stał się przesłanką w zasadzie analogiczną do tej, jaką mają inne, konstytutywne przesłanki małżeństwa. Co istotne przy tym i co wyraźnie podkreślić trzeba - obostrzenie to nie ma charakteru powszechnego; nie dotyczy nupturientów zamierzających zawrzeć małżeństwo przed kierownikiem USC lub konsulem (art. $1 \S 1$ i 4 k.r.o.) a odnosi się tylko do tych, którzy zamierzają zawrzeć małżeństwo w formie wyznaniowej ze skutkami cywilnymi.

Istniejący stan rzeczy trudno uznać za właściwy. I to tym bardziej, że podniesienie omawianego zaświadczenia do rangi jednej z przesłanek wywierania przez małżeństwo wyznaniowe skutków cywilnych ani nie wynika z treści Konkordatu, ani też nie było zabiegiem planowanym w toku wskazanych wyżej nowelizacji dostosowujących ${ }^{32}$.

Niezależnie od powyższego, analiza regulacji dotyczących zagadnienia tytułowego ujawnia istnienie jeszcze innego, swoistego paradoksu. Na kanwie uwag powyższych nie sposób bowiem nie zauważyć, iż z jednej strony ustawodawca mimo, iż nie określa wprost charakteru prawnego omawianego zaświadczenia i nie określa expressis verbis skutków jego braku, wprowadza takie regulacje, których stosowanie powoduje, iż w przypadku braku zaświadczenia - wystawienie aktu małżeńskiego nie jest możliwe.

$\mathrm{Z}$ drugiej strony, ten sam ustawodawca w art. 16 k.r.o. wyraźnie stanowi, iż w przypadku braku ważnego pełnomocnictwa lub sądowego zezwolenia na zawarcie małżeństwa przez pełnomocnika, małżeństwo może zostać unieważnione ale jednocześnie nie precyzuje bliżej, kto i jak miałby weryfikować spełnienie tego wymogu w przypadku małżeństw zawieranych w trybie art. $1 \S 2$ i 3 k.r.o. Procedura poprzedzająca wystawienie

32 Sobański 2003, 31. 
zaświadczenia o braku okoliczności wykluczających zawarcie małżeństwa nie określa w tym względzie żadnych mechanizmów kontrolnych a samo zaświadczenie nie przewiduje w swej treści żadnej tego rodzaju wzmianki lub adnotacji ${ }^{33}$.

Wniosku powyższego w niczym nie zmienia fakt, iż zgodnie z wymienionym wyżej art. 76 ust. 3 osoba zamierzająca wstąpić w związek małżeński obowiązana jest przedłożyć zezwolenie sądu, gdy jest ono wymagane przepisami k.r.o. oraz pełnomocnictwo, jeśli małżeństwo ma być zawarte przez pełnomocnika. Wymóg ten jest w pełni zrozumiały i jasny w przypadku małżeństw zawieranych w trybie art. $1 \S 1$ i 4 k.r.o. Nie ulega bowiem wątpliwości, iż to właśnie na organie przyjmującym oświadczenie stron o wstąpieniu w związek małżeński, spoczywa obowiązek weryfikacji zarówno tożsamości podmiotów, które oświadczenie to składają, jak i ewentualnego pełnomocnictwa dla dokonania takiej czynności. W przypadku jednak małżeństw wyznaniowych ze skutkami cywilnymi, sytuacja wyraźnie komplikuje się. Wynika to zarówno z faktu, iż wystawienie zaświadczenia i data zaślubin $\mathrm{z}$ reguły są czynnościami rozłożonymi w czasie i uczestniczą w nich różne osoby (kierownik USC i duchowny), jak i ze specyfiki matrimonium per procura. Ze względów losowych do ustanowienia pełnomocnika może wszak dojść już po wystawieniu przez kierownika USC zaświadczenia o braku okoliczności wyłączających zawarcie małżeństwa i w takim przypadku rzeczą oczywistą jest, iż kierownik USC istnienia pełnomocnictwa i zgody sądu zweryfikować już nie może. Także i sąd procedujący w przedmiocie zgody na zawarcie małżeństwa przez pełnomocnika nie będzie podmiotem kontrolnym, gdyż kwestia ta nie należy do przedmiotu sprawy i do badania ważności pełnomocnictwa sąd obligowany nie jest ${ }^{34}$.

Uwagi powyższe prowadzą zatem do wniosku, iż zaświadczenie o braku okoliczności wykluczających zawarcie małżeństwa, mimo, iż zyskało znaczenie nieproporcjonalne do swej roli, „nie rozpoznaje” specyfiki mał-

33 Na marginesie odnotować należy, że również wystawiane przez osobę duchowną zaświadczenie stwierdzające, że oświadczenia o wstąpieniu w związek małżeński zostały złożone w obecności duchownego - sporządzane według załącznika nr 27 do wskazanego wyżej rozporządzenia Ministra Spraw Wewnętrznych z 29 stycznia 2015 r. w sprawie wzorów dokumentów wydawanych z zakresu rejestracji stanu cywilnego - również takiej adnotacji nie przewiduje.

34 Szerzej zob. Świto, Tomkiewicz, 2018, 14-24. 
żeństw wyznaniowych ze skutkami cywilnymi zawieranymi per procura i w tym przypadku de facto właściwych funkcji gwarancyjnych nie spełnia. To, czy mankament ten należałoby konwalidować poprzez ewentualną nowelizację art. $8 \S 3$ k.r.o. czy też poprzez doprecyzowanie treści i procedury wystawiania analizowanego zaświadczenia, pozostaje kwestią otwartą ${ }^{35}$.

\section{BIBLIOGRAFIA}

Borysiak, Witold. 2014. W: Kodeks rodzinny i opiekuńczy. Komentarz, red. Jacek Wierciński. Warszawa: LexNexis.

Domański, Maciej. 2017. „Komentarz do art. 4 k.r.o.”. W: Kodeks rodzinny i opiekuńczy. Komentarz, red. Konrad Osajda i inni. Warszawa: C.H. Beck.

Haak, Henryk. 1999. Zawarcie malżeństwa. Komentarz. Toruń: TNOiK.

Krukowski, Józef. Krzysztof Warchałowski. 2000. Polskie prawo wyznaniowe, Warszawa: Wydawnictwo Prawnicze PWN.

Majer, Piotr. 2001. „Uwagi odnośnie do małżeństwa konkordatowego: art. 10 konkordatu z 1993 r. a ustawodawstwo państwowe", Ius Matrimoniale 6(12): 145-163.

Majer, Piotr. 2004. „Małżeństwo jako przedmiot zainteresowania Kościoła i Państwa - prawo kanoniczne a małżeństwo cywilne". W: Prawo wyznaniowe w systemie prawa polskiego, red. Artur Mezglewski, 255-286. Lublin: Wydawnictwo KUL.

Piasecki, Kazimierz, i inni. 2011. Kodeks rodzinny i opiekuńczy. Komentarz. Warszawa: Wolters Kluwer Polska.

Smyczyński, Tadeusz. 2002. „Odpowiedzialność odszkodowawcza duchownego z powodu naruszenia prawa przy zawieraniu małżeństwa”. Ruch Prawniczy, Ekonomiczny i Socjologiczny 64(2): 165-177.

Sobański, Remigiusz. 2003. „Zaświadczenie z urzędu stanu cywilnego a przesłanki małżeństwa konkordatowego". Państwo i Prawo 5: 30-33.

Świto, Lucjan. 2014. „Zasada favor matrimonii w Kodeksie Prawa Kanonicznego z 1983 r.”. W: Favor matrimonii? Teoria i praktyka, red. Lucjan Świto, Małgorzata Tomkiewicz, 59-70. Olsztyn: Wydział Teologii UWM.

Świto, Lucjan. Małgorzata Tomkiewicz. 2018. „Czynności administracyjne i cywilnoprawne poprzedzające zawarcie małżeństwa konkordatowego przez pełnomocnika w Polsce", Annales Canonici 2: 14-24.

35 Tamże. 
Tunia, Anna. 2017. „Procedura zawarcia małżeństwa konkordatowego - administracyjna czy cywilna?”. Acta Universitatis Lodziensis. Folia Iuridica 81: 83-97.

Zielonacki, Andrzej. 1982. Zawarcie matżeństwa. Wrocław: Zakład Narodowy im. Ossolińskich.

Żurawińska, Oliwia. 2012. „Małżeństwo konkordatowe zawarte przez pełnomocnika (uwagi na tle prawa polskiego i kanonicznego)". Rejent 3: 131-157.

CERTIFICATE OF NO IMPEDIMENTS TO MARRIAGE IN THE MATRIMONIUM PER PROCURA PROCEDURE

Summary

This paper presents normative solutions concerning the issuing procedure, the content and the significance of the certificate of no impediments to marriage in the context of regulations related to marriage by proxy (matrimonium per procura). The principal aim and the research problem posed in the article pertain to the question of the specific circumstances this document concerns. Do the control mechanisms accompanying the issuing of this certificate cover the requirements specified in Art. 6.1 of the Family and Guardianship Code, and do they recognize the specificity of marriage contracted by proxy? What is the actual meaning of the phrase used in Art. 8.1 of the Family and Guardianship Code, stating that a priest "cannot accept the declarations referred to in Art. 2.1 [of the Family and Guardianship Code]" without having been presented with the said certificate, and does the prohibition set forth in this regulation prove that the certificate of no impediments to marriage is the essential factor?

The paper puts forward the hypothesis that while the idea itself is undoubtedly justified, the adjustment of the regulations of the Family and Guardianship Code and the Registry Office Records Act to ensure compliance with the Concordat has gone too far in the matter under discussion. It has resulted in the introduction of restrictions establishing a clear primacy of formalism over the favor matrimonii principle and has given rise to different assessments of the nature of the said certificate, including opinions claiming the constitutive nature of this document. For persons intending to enter into marriage in the religious form with civil effects, the requirement to present a legally valid certificate has become a condition basically parallel to other, constitutive conditions to marriage, while this restriction is not of general nature. It does not apply to couples intending to contract marriage before the head of a registry office or a consul (Art. 1.1 and Art. 1.4 of the Family and 
Guardianship Code), and refers only to those who intend to enter into marriage in the religious form with civil effects.

The existing state of affairs can hardly be regarded as appropriate. Another deficiency of the current regulations also arises from the fact that the certificate of no impediments to marriage, although it has gained disproportionate importance, does not "recognize" the specificity of religious marriages with civil effects contracted per procura, and in this case does not duly fulfil its guaranteeing functions.

Key words: marriage; marriage by proxy; proxy; certificate of no impediments to marriage; impediments to marriage; churches and religious organizations

Tłumaczenie własne autorów 